\title{
KESETIAAN DALAM PERKARA KECIL SEBAGAI JALAN KEKUDUSAN
}

\author{
Yohanes Anjar Donobakti \&Rafael C. Sinurat* \\ Program Studi Ilmu Filsafat, Fakultas Filsafat, Unika Santo Thomas \\ Email: johanesadb2015@yahoo.com
}

\begin{abstract}
Abstrak
Orang-orang beriman kristiani, sejak menerima baptisan, sudah mengarahkan hidupnya menuju kepada kekudusan. Mereka dipanggil untuk bertumbuh dalam kekudusan, yaitu mengalami persatuan dengan Allah sumber kekudusan. Banyak jalan kekudusan, salah satunya bisa dicapai dengan cara melakukan perkara-perkara kecil. Jalan ini menuntut semua orang beriman untuk melakukan rutinitas harian dengan setia seturut nasihat Injil. Ketika seseorang melakukan perkara dan pekerjaan kecil dan sederhana dengan setia, pada saat itulah Kristus hadir, melimpahkan rahmat-Nya, dan memberikan cinta-Nya yang besar. Ketika orang-orang beriman melakukan perkara-perkara kecil dan sederhana dengan setia, ciinta, dan sukacita yang besar, mereka berada dalam jalan menuju kekudusan. Santa Theresia Lisieux melalui "jalan kecilnya" terutama dalam kesetiaannya melakukan perkara-perkara kecil memberikan suatu teladan bagi setiap orang beriman dapat sampai kepada kekudusan itu.
\end{abstract}

Kata-kata kunci: Santa Theresia Lisieux, Kesetiaaan, Perkara kecil, Jalan Kecil, Kekudusan.

\section{Pengantar}

Panggilan menuju kekudusan sudah ada sejak zaman Perjanjian Lama, terutama lewat Abraham dan Musa. Misalnya, Allah bersabda kepada Musa di gunung Sinai, "Berbicaralah kepada segenap umat Israel dan katakan kepada mereka: Kuduslah kamu, sebab Aku, TUHAN, Allahmu kudus" (Im 19:2). Dalam perjanjian Baru, jalan menuju kekudusan ini terwujud secara sempurna dalam diri Yesus Kristus. Yesus

\footnotetext{
* Yohanes Anjar Donobakti, Doktor of Philosophy; Southeast Asia Interdisciplinnary Development Institute; dosen tetap pada Fakultas Filsafat Unika St. Thomas, Sumatera Utara. Rafael C. Sinurat sekarang adalah mahasiswa S-2 Program Magister Filsafat di Universitas Katolik Santo Thomas Sumatera Utara semester 1.
} 
menyebut hanya Allah Bapa yang Kudus (Mat 5:48). Panggilan untuk sampai pada kekudusan ini diteruskan dan disampaikan oleh Gereja kepada semua anggota orang, khususnya orang kristiani. Konsili Vatikan II dalam Lumen Gentium menegaskan bahwa semua orang yang telah dibaptis bertanggungjawab untuk memberikan kesaksian tentang kasih Allah dalam diri Yesus Kristus. Dalam kesaksian itu semua umat kristiani serentak dipanggil untuk bertumbuh dalam kekudusan. ${ }^{1}$

Namun, apakah kekudusan hidup masih menjadi perhatian dan penghendakan dari setiap orang, mengingat banyaknya tantangan dan paham yang bisa mengaburkan, menjauhkan dan membelokkan jalan hidup orang beriman menuju kekudusan itu. Bahkan ada orang yang masih beraggapan bahwa menjadi kudus berarti harus melakukan perkara-perkara besar dan hebat. Apalagi, dewasa ini telah terjadi perubahan-perubahan yang sangat cepat dan mendalam di berbagai belahan dunia yang bisa mempengaruhi sikap dan tindakan setiap manusia dalam mengejar makna kehidupan. Dalam hal ini, usaha manusia untuk mencapai kekudusan yang didasari oleh suatu keinginan untuk hidup kudus dan secara terbuka untuk mewartakan kekudusan itu masih belum menjadi prioritas utama yang diminati orang masa kini. ${ }^{2}$

Paus Fransiskus dalam seruan apostolik Gaudete et Exsultate no. 14 menegaskan bahwa semua umat kristiani dipanggil kepada kekudusan dan menghidupinya dengan caranya masing-masing menurut profesi dan pekerjaan harian yang konkrit, entah sebagai seorang ayah, ibu, pelajar, pengacara dan sebagainya. Kekudusan itu nyata dapat diperoleh oleh setiap orang dengan cara melakukan hal-hal kecil dalam kehidupan sehari-hari. Tindakan yang sesuai dengan apa yang telah diserukan oleh Paus Fransiskus dapat ditemukan dalam semangat hidup Santa Theresia Lisieux (untuk selenjutnya akan ditulis dengan Theresia). Selama hidupnya di dalam biara Karmel, Theresia tidak pernah melakukan halhal yang luar biasa bahkan hidupnya tersembunyi sehingga orang-orang yang ada dalam biara tidak mengetahui rahasianya. Theresia

\footnotetext{
1 Konsili Vatikan II, "Konstitusi Dogmatis tentang Gereja" (Lumen Gentium), dalam Dokumen Konsili Vatikan II, diterjemahkan oleh R. Hardawiryana (Jakarta: Dokumentasi dan Penerangan KWI-OBOR, 1993) no. 5.

2 Segundo Galilea, Menjadi Murid Kristus (Jakarta: Obor, 1996), hlm. 26.
} 
mengupayakan agar dirinya mampu mencapai kekudusan dengan setia melakukan perkara-perkara kecil dan sederhana. ${ }^{3}$

Pandangan Theresia mengenai kekudusan ini meluruskan kembali suatu pandangan yang sering keliru mengenai jalan menuju kekudusan. Kebanyakan orang berpikir bahwa kukudusan itu hanya dapat dicapai dalam perkara-perkara besar seperti, bermati raga, puasa, penyiksaan diri dan melakukan mukzijat. ${ }^{4}$ Pengalaman dan pengahayatan Theresia akan kesetiaan dalam perkara kecil membuka pandangan dunia bahwa semua orang dapat menjadi kudus dan mencapai kesempurnaan.

\section{Sekilas Tentang Santa Theresia Lisieux}

Theresia, yang mempunyai nama kecil Fransiska Theresia, lahir pada 2 Januari 1873 di Alencon, Perancis. Ia dilahirkan dari keluarga yang sungguh beriman dan sederhana. Ayahnya bernama Louis Martin dan ibunya bernama Zelie Guerin. Orang tua Theresia menikah pada tanggal 13 Juli 1858 dan menetap di Alencon. Dari pernikahan tersebut, Tuhan mengaruniakan mereka sembilan orang anak. Namun dua orang putera dan dua orang puteri mereka meninggal pada waktu bayi sehingga yang hidup semuanya adalah perempuan. Zelie Guerin (ibu Theresia) meninggal karena penyakit kanker. Kerinduan Theresia yang begitu besar kepada Yesus melahirkan keinginan untuk menjalani hidup secara khusus sebagai biarawati. Pada usia 15 tahun, ia diberi izin khusus oleh Bapa Paus Leo XIII untuk masuk biara dan pada tanggal 9 April 1888 Theresia diterima masuk biara Karmel di Lisieux sebagai seorang postulan. Ia juga mendapat nama yang baru menjadi "Therese de I' Enfont-Jesus" (Theresia dari Kanak-kanak Yesus). Pada tanggal 10 Januari 1889, Theresia menerima pakaian biara Karmel sebagai seorang novis. Sebagai suster Karmelit, ia melakukan segala tugas pelayanan dengan setia dan penuh tanggung jawab karena didorong oleh cintanya kepada Yesus. Oleh karena itu juga menerima nama biara yang kedua yakni, "De la Sainte Face" (Theresia dari Wajah Suci). Dengan pemberian nama itu, Theresia mengalami perkembangan rohani yang besar dalam hidupnya. Pada tahun 1893, ia mendapat tugas sebagai wakil pimpinan novis dan

\footnotetext{
3 Yohanes Indrakusuma, Kasih, Kepercayaan dan Pasrah: Jalan Kanak-kanak Rohani Theresia Lisieux (Jawa Barat: Pertapaan Shanti Buana, 2003), hlm. 145.

${ }^{4}$ Yohanes Indrakusuma, Kasih, Kepercayaan ..., hlm. 145.
} 
menulis karyanya “jalan kecil”. Ia meninggal dunia pada tanggal 30 September 1897, meninggal pada usia 24 tahun. Pada tahun 1923, Paus Pius XI membeatifikasinya sebagai seorang beata. Kemudian Paus Pius XI juga mengkanonisasinya sebagai seorang santa pada tahun 1925. Ia termasuk orang kudus terbesar pada zamannya dan berpengaruh sampai saat ini. Ia adalah seorang Pujangga Gereja karena tulisannya yang memberikan inspirasi bagi banyak orang di seluruh dunia. Selain itu, Theresia juga dijadikan sebagai pelindung misi bersama dengan Santo Fransiskus Xaverius dan pelindung bagi tanah kelahirannya, Perancis, setelah Santa Jeanne d'Arc. ${ }^{5}$

\section{Kesetiaan dalam Perkara Kecil sebagai Jalan Kekudusan}

\section{Pengertian Kesetiaan}

Menurut Kamus Besar Bahasa Indonesia, kesetiaan berasal dari kata setia yang berarti berpegang teguh pada pendirian, keteguhan hati dan kepatuhan. ${ }^{6}$ Dalam Bahasa Yunani, kesetiaan disebut dengan istilah "pistis" yang dihubungkan dengan iman. Istilah "pistis" mempunyai kesamaan arti dengan kata Ibrani "emuna" yang berasal dari "emet" artinya kebenaran. Maka kesetiaan adalah iman yang bukan hanya pengetahuan untuk menerima suatu kebenaran melainkan keterlibatan diri secara penuh kepada pribadi yang lain yaitu kepada Allah atau kepada manusia sebagai sumber kebenaran. Dalam bahasa Inggris, kesetiaan disebut loyality yang artinya solidaritas, cinta kasih yang diamalkan, cinta kasih yang tetap dan pasrah. ${ }^{7}$

Dalam Kitab Suci, kesetiaan kerap kali dipakai untuk menunjukkan sifat Allah. Sifat itu erat sekali hubungannya dengan kerahiman atau kasih karunia yang dinyatakan oleh Allah sendiri kepada

\footnotetext{
5 Theresia Lisieux, The Autobiography of Therese of Lisieux: The Story of a Soul, diterjemabkan oleh John Beevers (New York: Doubleday and Company Inc. 1957)...., hlm. 10; bdk. Theresia Lisieux. Aku Percaya akan Cinta Kasih Allab (Judul Asli: Histoire de Une Ame), diterjemahkan oleh biarawati Karmel Bajawa (Yogyakarta: Kanisius, 1985), hlm. 16-17. Ida Friederike Gorres, Wajah Tersembunyi: Kehidupan Theresia Lisieux, (Judul asli: Het Verborgen Gelaat) diterjemahkan oleh biarawati Karmel Bajawa.(Yogyakarta: Kanisius. 1985), hlm. 120-121.

${ }^{6}$ Departemen Pendidikan Nasional, Kamus Besar Bahasa Indonesia, Edisi Ketiga (Jakarta: Balai Pustaka, 2002), hlm. 1056.

7 Xavier Leon-Dufuor, Ensiklopedi Perjanjian Baru (judul asli: Dictionnaire du Nonveau Testament), disadur oleh Stefan Leks dan A. S. Hadiwiyata (Yogyakarta: Kanisius, 1990), hlm. 506.
} 
manusia. Kesetiaan dalam terang Kitab Suci menunjukkan unsur yang amat mencolok yaitu ketetapan, keteguhan, kesabaran dan kasih Allah yang mau terus-menerus mencintai umat kesayangan-Nya walaupun mereka sering gagal. Kasih yang abadi tercermin dalam kesetiaan yang tidak kunjung henti. Allah selalu mengasihi bangsa-Nya dan menyelenggarakan kebaikan-Nya tanpa henti. Sikap Allah yang selalu mengasihi itu disebut sebagai kesetiaan. ${ }^{8}$

\section{Kesetiaan dalam Perkara Kecil}

Di dalam Gereja, Theresia mendapat tempat untuk mewakili orang-orang yang mempunyai sikap heroik dalam melakukan perkaraperkara kecil dengan setia. Theresia lebih memilih untuk menapaki jalan kecil yang tersembunyi dalam biara dan tidak diketahui oleh banyak orang. Namun dalam menapaki jalan-jalan kecil ini dengan setia melakukan perkara kecil dan sederhana. Theresia sungguh-sungguh mengagumkan karena tampak luar biasa dalam hal-hal yang biasa, pekerjaan kecil, dan sederhana yang dilakukan dengan cinta kepada Allah dan denga sukacita yang besar.. Theresia tidak pernah melewatkan satu korban pun untuk melatih kebajikan dalam dirinya sehingga ia sampai kepada kemartiran cinta kasih dalam hidupnya. Di dalam perbuatan atau perbuatan-perbuatan yang kecil, Theresia menyatakan suatu kekuatan adikodrati yang besar. Tanpa suatu kepura-puraan dan jauh dari formalisme, Theresia dapat menjadikan hidupnya sebagai model dari cinta kasih yang murni. Walaupun ia kehabisan tenaga dan mengalami kelelahan namun ia tetap berjalan terus karena dalam dirinya ada suatu kerinduan dan semangat bagi penyelamatan jiwa-jiwa. ${ }^{9}$

- Semangat dalam diri Theresia ini bertolak belakang dengan keinginan orang pada umumnya. Di dunia ini orang selalu ingin menjadi besar, ingin dihargai, sementara Theresia sendiri ingin agar orang mencintai kekecilan dan kepapan dirinya masing-masing. Dengan

\footnotetext{
${ }^{8}$ St. Darmawijaya, Kesetiaan Suatu Tantangan (Yogyakarta: Kanisius, 1989), hlm. 47-50.

${ }^{9}$ Yohanes Indrakusuma, Ketujuh Karunia Roh Kudus Dalam Hidup St. Theresia Lisieux (Jawa Barat: Pertapaan Shanti Buana, 2004), hlm. 39.
} 
mencintai kekecilan dan kepapaan diri masing-masing, menurut Theresia setiap orang akan menjadi kurban bakaran bagi kerahiman Allah. ${ }^{10}$

Ada tiga hal utama yang menjadi dasar jalan kecil yang harus dihidupi oleh Theresia untuk sampai kepada kekudusan dan memperoleh kesempurnaan. Ketiga jalan itu menjadi pedoman dan prinsip hidup spiritual Theresia untuk mau menjadi kecil dan dengan setia melakukan perkara-perkara kecil setiap hari. Ketiga hal itu adalah sebagai berikut:

\section{Kebajikan-Kebajikan Religius}

Theresia menyadari bahwa hidup membiara merupakan sekolah pengudusan bagi dirinya. Dengan menjadi seorang biarawati, Theresia berusaha mengejar cita-cita hidup menjadi orang kudus dengan menjadi suster Karmelit. Dia melihat panggilannya secara sadar dan menyeluruh. Ia tidak berkhayal tentang hidup Karmel. Sejak semula ia mengatakan:

"Saya mengerti bahwa dengan masuk biara saya tidak mempunyai khayalan, bahwa saya akan disanjung atau dimanaja karena menjadi yang termuda. Bahagia karena bisa selalu bertemu dengan kakak-kakakku. Sama sekali tidak."11

Sebagai seorang religius ia berusaha untuk mencapai kesempurnaan cinta kasih melalui kurban-kurban yang disempurnakan. Theresia hanya ingin memberikan cinta kasihnya semata-mata kepada Allah. Cinta yang diberikan oleh Theresia itu, tidak hanya berupa katakata saja. Cinta itu ia hayati dalam sikap dan perbuatan sehari-hari dengan melakukan tugas harian dan rutinitas yang kelihatan biasa-biasa. Namun semua itu dilakukan olehnya dengan penuh kesadaran dan cinta kasih. Jalan-jalan kecil yang ditempuh dan dihayati Theresia sesuai dengan kebajikan/keutamaan religius atau nasihat Injili.

\section{$\underline{\text { Kemiskinan }}$}

Penghayatan kemiskinan yang dilakukan oleh Theresia tidak mencolok seperti yang dilakukan Santo Fransiskus Assisi. Namun penghayatan kelepasan dan kemiskinannya tidak kalah radikal dibanding Santo Fransiskus tersebut. Ia sungguh mengikuti Yesus dalam jalan

\footnotetext{
${ }^{10}$ Yohanes Indrakusuma, Kasih, Kepercayaan ..., hlm. 49.

${ }^{11}$ Yohanes Indrakusuma, Kasih, Kepercayaan ..., hlm. 148.
} 
kelepasan dan pengosongan diri. Theresia mengatakan bahwa setelah menerima pakaian biara yaitu ketika masuk sebagai novis, ia menerima terang berlimpah-limpah dalam penghayatan kaul kemiskinan. Ia mengatakan, "Saya benar-benar terdorong untuk memilih hal-hal dan barang-barang yang paling jelek dan paling buruk."12

Meskipun miskin akan harta duniawi, Theresia kaya akan Allah karena ia mempercayakan seluruh hidupnya tanpa batas kepada-Nya. Theresia sadar bahwa rahmat Allah selalu menaungi hidupnya. Ia mengatakan, "Segala-galanya adalah milik kita, segala-galanya diperuntukkan bagi kita, sebab di dalam Yesus kita mempunyai segala."13

Penghayatannya dalam kaul kemiskinan dapat dilihat dalam gagasan yang ditulis Theresia tentang kemiskinan, sebagai berikut:

"Kemiskinan adalah kerelaan untuk kehilangan bukan hanya barang-barang yang menyenangkan, tetapi bahkan yang sangat diperlukan. Sungguh tidak ada damai yang dapat dibandingkan dengan damai yang dimiliki oleh orang yang bersemangat miskin. Bila seseorang yang bersemangat miskin meminta sesuatu dan apa yang dimintanya tidak hanya ditolak bahkan orang berusaha merampas apa yang dimilikinya, maka ia mengikuti nasihat Tuhan Yesus: "Berikanlah juga mantolmu, kepada orang-orang yang mengingini jubahmu" (Mat 5:40), artinya tidak hanya memberikan apa yang diminta tetapi memberikan apa yang sangat diperlukan."14

Theresia menjelaskan bahwa memberikan mantol berarti melepaskan hak yang terakhir dan menganggap diri sebagai hamba untuk orang lain. Ia menambahkan demikian:

"Bila orang melepaskan mantolnya, maka bebannya menjadi lebih ringan dan ia bisa berjalan lebih cepat. "Siapapun yang memaksa engkau berjalan sejauh satu mil, berjalanlah bersama dia sejauh dua mil," sabda Tuhan (Mat 5:41). Bagiku tidak cukup hanya memberikan kepada mereka yang meminta, saya mencoba

\footnotetext{
${ }^{12}$ Yohanes Indrakusuma, Kasih, Kepercayaan ..., hlm. 149.

${ }^{13}$ Koen de Meester, Tangan Kosong ..., hlm. 137.

${ }^{14}$ Yohanes Indrakusuma, Kasih, Kepercayaan ..., hlm. 149-150.
} 
mengenali keinginan-keinginannya; merasa diri wajib dan mendapat kehormatan untuk bisa melayaninya. Bila orang merampas apa yang saya pakai, saya akan menunjukkan sikap sukacita karena dilepaskan dari barang itu." 15

Maka pengalaman Theresia untuk mengikuti Yesus adalah suatu langkah yang lebih dalam untuk mengenal bahwa mengasihi Yesus tidak hanya berasal dari keinginan manusiawi semata tetapi datang dari kehendak Allah. Theresia menegaskan bahwa kehendak Allah akan kasih tidak hanya berguna untuk pertobatan orang berdosa saja namun sebagai bentuk penyerahan diri manusia secara total kepada-Nya. ${ }^{16}$

\section{$\underline{\text { Kemurnian }}$}

Kemurnian dalam pengertian umum adalah kondisi yang bersih dari kepalsuan atau unsur asing. Kemurnian atau "chastity" dalam bahasa Inggris menunjuk pada arti keutamaan moral dalam laku mengendalikan dan mengatur rasa nikmat genital yang merupakan kurnia dari Tuhan pada manusia sebagai 'jaminan' kelangsungan bangsa manusia. Kemurnian (castitas) adalah buah dari kesopanan dan pengendalian diri. Sebagai keutamaan, kemurnian dapat bersifat kodrati dan dapat juga bersifat adikodrati. Kemurnian bersifat kodrati ketika akal sehat memberi arahan kepada seseorang bahwa penyalahgunaan kenikmatan seksual genital pada dasarnya tidak sesuai dengan martabat yang ada dalam diri manusia. Adanya kontrol atas daya kenikmatan seksual genital berdasar akal sehat itu disebut sebagai keutamaan kodrati. Sementara jika laku hidup murni yang dikaulkan dan karena termotivasi untuk hidup demi Kerajaan Surga (bdk. Mat 19:10; 1Kor 7:12), maka cara hidup demikian menjadi status yang bersifat adikodrati. Keutamaan yang bersifat adikodrati ini adalah anugerah 'kharisma' dari Tuhan. Dalam peristiwa ini, orang tertangkap oleh Kerajaan Surga dengan hidup dalam kaul kemurnian dan penyerahan diri seutuhnya kepada Tuhan. ${ }^{17}$

Dalam penghayatan kaul kemurniaan sebagai seorang biarawati Karmel, Theresia sungguh-sungguh merupakan seorang yang sangat

\footnotetext{
15 Yohanes Indrakusuma, Kasih, Kepercayaan ..., hlm. 150.

${ }^{16}$ Paulinus Yan Olla, Dipanggil Menjadi Saksi Kasih (Yogyakarta: Kanisius, 2008), hlm. 95.

${ }^{17}$ J. Sunarka, Kaul Kemurnian ..., hlm. 343-344.
} 
murni. Ia adalah seorang malaikat kemurnian karena memiliki rahmat khusus yang ia peroleh sejak usia 4 tahun. Pada waktu itu, di dalam hatinya sudah ada keinginan untuk menjadi milik Kristus, ingin mencintai Kristus dan rindu bersatu dengan Kristus. Terkadang dari dalam mulutnya keluar kata-kata kerinduan ingin menjadi murni seperti serafim. Oleh karena itu, Theresia memelihara seluruh tenaganya untuk mencintai Allah semata. Ia mengerti bahwa hanya cinta yang mampu mengarahkannya menuju kesempurnaan hidup. ${ }^{18}$

Maka dalam diri Theresia dapat dilihat cinta akan penderitaan sebagai suatu kurban kasih kepada Yesus. Ia menerima penderitaan itu dengan senyum dan penyerahan diri total kepada Allah sebagai bentuk penghayatan kemurnian hidupnya. Cara yang dilakukan Theresia sangat sederhana yaitu: mencintai, menderita dan tersenyum. Semua yang dilakukannya adalah hal-hal kecil yang dilakukan dengan penuh kesetiaan karena cintanya kepada Allah. ${ }^{19}$

\section{$\underline{\text { Ketaatan }}$}

Ketaatan Theresia bersumber dari ketaatan Yesus Kristus kepada Bapa. Ketaatan Yesus kepada Bapa-Nya mengajak Theresia untuk bergerak maju menuju kedalaman hidup agar ia dapat berjumpa dengan Yesus. Sebagai seorang biarawati Theresia memahami dan menerima bahwa ketaatan religius menuntut kesetiaan walaupun ia melihat bahwa tugas-tugas yang diberikan kepadanya sama sekali tidak menarik. Ia harus menerima kenyataan bahwa kemiskinan, keterbatasan, kepicikan dan kekerasan ada dalam lingkungan biaranya. Kenyataan itulah yang tidak hanya diterima namun harus dicintainya. Dengan menerima dan mencintai orang-orang yang ada di sekitarnya, ia memenuhi tuntutan peraturan yang ada di biara sebagaimana Yesus Kristus memerintahkan kepada para rasul untuk saling mencintai. ${ }^{20}$

Theresia membiarkan diri dibentuk oleh semangat Karmel yang pada akhirnya meresapi seluruh hidupnya. Ia benar-benar menjadi seorang teladan bagi sesama temannya di dalam biara. Theresia menjadi

\footnotetext{
${ }^{18}$ Yohanes Indrakusuma, Kasih, Kepercayaan ..., hlm. 151.

${ }^{19}$ Yohanes Indrakusuma, Ketujuh Karunia ..., hlm. 43.

${ }^{20}$ Ida Friederike Gorres, Wajab Tersembunyi ..., hlm. 340-341.
} 
teladan ketaatan dan kecermatan dalam menghayati segala peraturan biara. Ia dengan peka dan rela menyesuaikan diri dengan kehendak Allah bahkan yang paling kecil sekalipun yaitu menghayati segala peraturan biara sebagai bentuk ungkapan bahwa ia melaksanakan kehendak Allah. ${ }^{21}$

Di dalam diri pimpinannya, ia selalu melihat kehadiran Allah karena ia menghayati ketaatan dengan setia. Dalam ketaatan, Theresia menemukan suatu sarana yang paling aman dan efektif untuk melaksanakan kehendak Allah sehingga ia berkenan kepada-Nya dalam segala sesuatu. Oleh karena itu ia mengatakan:

"Oh Tuhan, betapa kami dibebaskan dari banyak kebingungan dan kekuatiran melalui kaul ketaatan. Betapa bahagianya para religius yang sederhana yang setia melakukan kehendak atasannya sebagai pedoman mereka. Pastilah mereka berada dalam jalan kebenaran. Mereka tidak usah takut bahwa mereka akan keliru, juga apabila tampak jelas bagi mereka bahwa pimpinannya keliru. Tetapi bila orang tidak mengikuti kompas itu, maka akan mudah tersesat dan dia akan menempuh jalan-jalan kering dimana air rahmat akan segera hilang." 22

Ia juga tidak pernah meminta penghiburan untuk dirinya sendiri. Segala sesuatu diterimanya dari Allah dengan penuh sukacita. Kehendak Allah dalam dirinya selalu terpancar dari wajahnya. Hal itu tampak ketika segala kesukaran dan godaan yang dahsyat menimpanya, ia selalu menghadirkan wajah yang ramah dan ceria. Menurutnya segala penderitaan adalah sebagai jalan bersahaja yang membawa orang untuk berharap hanya kepada Allah saja. Ia menuliskan demikian:

"Saya tidak akan meminta kepada Allah penderitaan yang lebih besar. Kalau Dia menambahnya, saya akan menanggungnya dengan gembira sebab semua itu datangnya dari Dia. Tetapi kalau saya memintanya, maka itu akan menjadi penderitaanku dan saya

\footnotetext{
${ }^{21}$ Yohanes Indrakusuma, Kasih, Kepercayaan ..., hlm. 151-152

22 Yohanes Indrakusuma, Kasih, Kepercayaan ..., hlm. 152.
} 
harus menanggungnya seorang diri. Padahal saya tidak pernah bisa menanggungnya sendirian." 23

Inilah bukti ketaatan Theresia yang total kepada Allah. Dalam tulisannya yang lain dikatakan bahwa ia tidak memiliki keinginan apaapa lagi kecuali ingin mencintai Yesus sampai akhir hidupnya. Tindakan taat yang dilakukannya ini menjadi pembimbing utama dalam melakukan kehendak Allah. Ia jeli melihat apa yang dikehendaki Allah dari dirinya untuk ia lakukan dengan sempurna demi ketaatan kepada-Nya. ${ }^{24}$

Ketaatan kepada kehendak Allah itu ia laksanakan melalui ketaatan terhadap kehendak pimpinannya. Theresia melihat hal itu sebagai suatu sarana yang pasti untuk mengenal Allah. Sementara itu, ia yakin bahwa ketika orang mulai menyimpang dari kebijakan yang dibuat pimpinan maka orang itu akan mudah tersesat dan memasuki suatu jalan yang kering sampai akhirnya ia tak bisa lagi menemukan jalan yang benar. Keyakinan Theresia untuk sampai pada kepastian ini membutuhkan suatu keyakinan iman yang mendalam. Sebab di dalam iman, orang menyadari bahwa segala sesuatu terjadi menurut penyelenggaraan Allah. Dengan demikian, dapat dikatakan bahwa ketaatan adalah ungkapan dari iman yang mendalam kepada Allah. ${ }^{25}$

\section{Mengakui Kekecilan dan Kekosongan}

Kekudusan Theresia tidak terletak pada perbuatan-perbuatannya yang besar namun pada tindakan-tindakan kecil dan sederhananya dalam hidup setiap hari. Tindakan-tindakannya ini selalu ia hayati dengan cinta yang mendalam. Hal ini dapat dilihat dari kisah yang ditulisnya atas perintah Pauline, kakaknya yang pada waktu itu menjadi pembesar biara. Kisah itu ditulis oleh Theresia dalam buku yang berjudul histoire d'une ame sebelum ia wafat dua setengah tahun kemudian. Dalam buku itu, ia sering menyebut dirinya sebagai bunga kecil. Ungkapan ini menunjukkan relasi yang akrab dan mendalam antara dirinya dengan Yesus. Baginya "bunga kecil" melambangkan cinta dan pengorbanan yang dilakukannya. Oleh karena itu ia menamakan diri sebagai bunga kecil sementara biara

\footnotetext{
${ }^{23}$ Yohanes Indrakusuma, Kasih, Kepercayaan ..., hlm. 134

${ }^{24}$ Ida Friederike Gorres, Wajab Tersembunyi ..., hlm. 308.

${ }^{25}$ Yohanes Indrakusuma, Kasih, Kepercayaan ..., hlm. 152.
} 
Karmel ia sebut sebagai ladang atau taman tempat bunga itu bertumbuh. Ia merasa bahwa Yesus selalu memperhatikan dan merawatnya sebagai bunga kecil sampai ia dapat bertumbuh dengan indah. ${ }^{26}$

Namun saat menjelang wafatnya, Theresia menyadari bahwa kepapaan dan pekerjaan-pekerjaanya tidak berarti apa-apa ketika dia harus tampil di hadapan Allah. ${ }^{27}$ Kesadaran akan ketidakberdayaan dan kepapaan ini merupakan bagian dari suatu karunia pengetahuan yang diterima oleh Theresia. Karunia ini menimbulkan suatu kerinduan di dalam dirinya untuk dapat masuk surga. ${ }^{28}$ Namun justru dalam kesadaran akan kepapaannya itu sekaligus tampak letak kebesaran Theresia akan kepercayaan yang kokoh pada kerahiman Allah. Cintanya yang sangat peka terhadap sesama membuatnya melupakan diri sendiri dan terus menghibur orang-orang yang ada di sekelilingnya dengan cinta kasih yang menyala. ${ }^{29}$ Ia menyerahkan seluruh dirinya tanpa syarat kepada Allah hanya demi kemuliaan-Nya dan demi kebahagiaan Gereja. Penderitaan-penderitaan yang dialami menyempurnakan cinta yang dimilikinya supaya cinta itu menjadi lebih murni dan suci. ${ }^{30}$

Pada saat fisiknya semakin melemah, Theresia tidak sedikitpun mengeluh atau menuntut melainkan dari dalam dirinya terpancar penyerahan diri yang total kepada Allah. Ia wafat karena cintanya kepada Allah. Hal ini sama seperti yang dikatakan oleh Santo Yohanes dari Salib bahwa ketika orang kudus meninggal, ia meninggal bukan karena kelemahan badannya tetapi karena cinta kasih Allah yang besar ada padanya. $^{31}$

Menurut Theresia untuk mengerti motivasi yang mendorong seseorang berbuat sesuatu terdapat suatu faal (tindakan luhur) di baliknya. Faal-faal utama cinta kasih dari Theresia adalah pertama,

\footnotetext{
${ }^{26}$ Theresia Lisieux, The Autobiography ..., hlm. 13-14; bdk. A. Sudiarja, Lima Kuntum ..., hlm. 34-35. Selain menyebutkan dirinya sebagai bunga kecil, Theresia juga menggambarkan dirinya sebagai burung kecil dan sebutir pasir, dan menyamakan dirinya dengan sebuah bola kecil dan kuas kecil.

${ }^{27}$ Ida Friederike Gorres, Wajah Tersembunyi..., hlm. 383.

${ }^{28}$ Yohanes Indrakusuma, Ketujuh Karunia ..., hlm. 85.

${ }^{29}$ Ida Friederike Gorres, Wajah Tersembunyi..., hlm. 383.

${ }^{30}$ Yohanes Indrakusuma, Kasih, Kepercayaan ..., hlm. 50-51.

${ }^{31}$ Yohanes Indrakusuma, Kasih, Kepercayaan ..., hlm. 56.
} 
menyenangkan hati Yesus. Dalam hal ini Theresia memandang Yesus tampak sedih dan menderita karena dosa-dosa yang dilakukan oleh umat manusia sehingga Theresia ingin menghibur dan menyenangkan hati Yesus. Kedua, cinta kasih yang murni. Menurut Theresia, melayani Tuhan tidak boleh mengharapkan adanya imbalan melainkan dengan hati yang gembira. Theresia memegang perkataan bahwa mengasihi berarti melupakan diri sendiri dimana seseorang tidak akan memperhitungkan untung atau rugi ketika membantu orang lain. Theresia hendak menyenangkan Yesus melalui persembahan yang indah dan ia meletakkannya di hadapan Yesus agar dapat dinikmati-Nya. Ketiga, melakukan segala-galanya karena cinta. Dalam setiap perbuatan sehebat apapun,yang paling bernilai di hadapan Allah ialah cinta yang mendorong orang melakukan perbuatan tersebut. Cinta kasih memberi arti dan nilai kepada pekerjaan-pekerjaan kecil dan sederhana sehingga pekerjaan apapun yang dilakukan tanpa cinta kasih mempunyai nilai yang sedikit di hadapan Allah. ${ }^{32}$

Dengan mencintai maka seseorang hidup bagi dia yang dicintai dan hanya memikirkan kebaikannya. Cinta telah mendorong para kudus untuk menggunakan seluruh kekuatannya bagi pewartaan Kerajaan Allah. Theresia memiliki hati yang selalu terarah kepada Allah karena dijiwai oleh semangat cinta kasih misioner yang besar. Baginya dorongan untuk dapat menjadi kudus terdapat dalam tindakan mengasihi. ${ }^{33}$ Sebab kesempurnaan Kristiani pertama-tama terdapat dalam kasih kepada Allah sebagai sumber hidup dan pemberi segala kebaikan. Melalui kasih itu, setiap orang dipersatukan dengan Allah dan memperoleh rahmat dari Allah sendiri. Oleh karena itu, menurut Theresia kasih kepada Allah adalah dasar dari segala sesuatu yang dilakukan oleh manusia sebagaimana kesetiaan Theresia tampak dalam tugas-tugas kecil yang dilakukannya demi cintanya kepada Allah semata. ${ }^{34}$

Cintanya kepada Allah dapat dilihat dari betapa kecilnya perbuatan-perbuatan yang dilakukannya namun penuh dengan kesetiaan. Ia melakukan tugas-tugas yang dipercayakan kepadanya dengan tulus dan

\footnotetext{
32 Yohanes Indrakusuma, Kasih, Kepercayaan ..., hlm. 107.

${ }^{33}$ Ida Friederike Gorres, Wajah Tersembunyi..., hlm. 383.

34 Yohanes Indrakusuma, Penyelenggaraan..., hlm. 85.
} 
ikhlas. Ia tidak mau merepotkan dan membuat orang lain sakit hati hanya karena tugas-tugas yang sederhana. Tetapi kesederhanaan yang kerap dilupakan oleh orang itulah yang menjadikan Theresia seorang yang besar di hadapan Allah. ${ }^{35}$

\section{Menjalin Kasih Persaudaraan}

Theresia membutuhkan waktu yang lama untuk memahami dengan jelas bahwa tempat teristimewa yang harus diduduki dalam kebersamaan adalah cinta kasih. Melalui cintanya kepada Allah, Theresia menemukan rahasia cinta kepada sesama hingga akhir hayatnya. Ia mengatakan: "Rahmat untuk mengerti kasih persaudaraan secara sempurna, dengan segala konsekuensinya, adalah salah satu rahmat yang terbesar." 36

Namun kasih kepada Allah itu tidak dapat dilepaskan dari kasih kepada sesama. Kasih kepada sesama merupakan luapan dan pancaran dari kasih kepada Allah sekaligus tanda yang pasti bahwa seseorang mempunyai kasih kepada Allah. Kasih kepada sesama tidak dapat menjadi sungguh-sungguh efektif bila tidak dilaksanakan dalam Allah dan demi Allah. ${ }^{37}$

\section{Cinta Kasih sebagai Hukum yang Baru}

Kasih kepada Allah dan sesama ini tampak dalam sikap Theresia melakukan cinta kasih maupun dalam hal lainnya. Ia menyebutnya sebagai sikap seorang anak kecil yang mengutamakan Allah di atas segala sesuatu. Ia mengungkapkan bahwa setiap orang harus menjadi seperti seorang anak kecil di hadapan Allah yang Maharahim. Dengan bersikap sebagai seorang anak kecil, ia hendak mempersatukan sikap keadilan dengan cinta kasih yang sering diabaikan oleh banyak orang. ${ }^{38}$

Di dalam Injil, Theresia menyelidiki bagaimana cara Yesus mencintai para murid-Nya. Ia mencintai mereka bukan karena bakatbakat yang mereka miliki atau kebajikan-kebajikan yang mereka lakukan. Yesus mencintai para murid karena mau membawa mereka masuk ke

\footnotetext{
35 Yohanes Indrakusuma, Kasih, Kepercayaan ..., hlm. 102.

${ }^{36}$ Yohanes Indrakusuma, Kasih, Kepercayaan ..., hlm. 155-156.

${ }^{37}$ Yohanes Indrakusuma, Penyelenggaraan ..., hlm. 81-82.

38 Yohanes Indrakusuma, Penyelenggaraan ..., hlm. 103-104.
} 
dalam Kerajaan Bapa-Nya. Oleh karena cinta-Nya terhadap para murid, Ia mau mati di salib sambil berkata, "Tidak ada kasih yang lebih besar daripada kasih seseorang yang memberikan hidup-Nya bagi sahabatsahabat-Nya, bagi orang-orang yang dicintai-Nya.” Dalam kata-kata Injil ini Theresia menemukan kebesaran kasih Yesus terhadap para muridNya. Walaupun para murid termasuk kalangan bawah dan umumnya tidak berpendidikan, Ia tetap mencintai mereka secara sempurna bahkan sampai mengurbankan hidup-Nya bagi para murid. ${ }^{39}$

Melalui kasih Yesus kepada para murid, Theresia telah belajar dan memasuki jalan cinta kasih. Ia memasuki jalan cinta kasih itu dengan penuh percaya dan langkah yang tenang. Tindakan yang dilakukan oleh Theresia ini hendak menegaskan bahwa iman manusia akan Allah harus diwujudkan dalam kenyataan sebab iman yang teguh dapat mengalahkan kuasa maut dan neraka. Dengan menempuh jalan cinta kasih ini Theresia ingin menyelamatkan banyak jiwa agar mereka mencintai Allah kembali dan memperoleh keselamatan dari cinta-Nya. ${ }^{40}$

Hal ini tampak dari tulisan Theresia di buku hariannya The Story of a Soul. Ia menulis demikian:

"Ketika saya bertindak dan berpikir dengan kasih, saya merasa bahwa Yesuslah yang bekerja dalam diri saya. Semakin dekat aku dipersatukan dengan Dia, semakin aku mengasihi semua yang tinggal di Karmel. Jika saya ingin kasih ini tumbuh lebih dalam dan iblis berusaha untuk menunjukkan kepada saya kesalahan seorang saudari, saya bergegas untuk memikirkan semua kebajikannya dan seberapa baik niatnya. Saya berkata kepada diriku sendiri bahwa meskipun saya telah melihatnya berbuat dosa, dia mungkin telah memenangkan banyak kemenangan rohani yang tidak saya ketahui karena kerendahan hatinya." ${ }^{21}$

\section{Peka akan Cinta Kasih}

Allah menganugerahkan rahmat kepada manusia agar mengenal dan mengalami diri-Nya. Pengenalan dan pengalaman akan Allah itu

\footnotetext{
${ }^{39}$ Yohanes Indrakusuma, Kasih, Kepercayaan ..., hlm. 156-158.

${ }^{40}$ Ida Friederike Gorres, Wajah Tersembunyi ..., hlm. 383.

${ }^{41}$ Theresia Lisieux, The Autobiography ..., hlm. 123.
} 
dapat dilakukan melalui dua cara yaitu studi ilmiah dan intuisi cinta kasih. Pengetahuan ilmiah tentang Allah yang mewahyukan diri memerlukan usaha yang tidak mudah. Manusia dengan akal budinya yang terbatas tidak dapat memahami misteri dan kebenaran Allah hanya dengan konsep-konsep semata. Kebenaran Allah jauh melampaui segala konsep dan pemikiran yang ada pada manusia. ${ }^{42}$ Theresia dengan pikirannya yang bersifat intuitif dan realistis mengenal dan mengalami Allah melalui tindakan cinta kasihnya. Dalam refleksinya yang mendalam, Theresia selalu berpegang teguh pada Injil. Ia mengatakan bahwa Injil mengajarkan manusia untuk mengasihi dan mencintai sesama dalam situasi apapun sebagai keutamaan untuk mencintai Allah. ${ }^{43}$

Sejak kecil Theresia telah memukan kehadiran Allah dalam segala ciptaan. Theresia memiliki karunia pengertian untuk mengenal Allah dan Putera-Nya, Yesus Kristus. Allah menganugerahkan rahmat pengertian kepada Theresia karena imannya yang sungguh murni diterangi oleh Roh Kudus. ${ }^{44}$ Ia mengatakan bahwa inti pencariannya selama ini ialah Allah sendiri. Allah mencintai Theresia dan menganugerahkan rahmat yang berlimpah-limpah kepadanya karena ia mempercayakan diri kepadaNya. $^{45}$

\section{Jalan Kekudusan}

\section{Pengertian Kekudusan}

Pengertian populer mengenai kekudusan secara turun-temurun diwariskan oleh generasi terdahulu dalam dikotomi dengan "dosa". Pengertian kudus dan dosa diajarkan oleh banyak agama dalam kategori moral (perilaku baik-buruk) dan legal (perilaku taat atau melanggar hukum). Kekudusan (kudus) diturunkan dari akar kata Latin, sacersacra-sacrum yang berarti suci dan bersih. ${ }^{46}$ Berakar dari asal kata ini,

\footnotetext{
${ }^{42}$ Yohanes Indrakusuma, Ketujub Karunia ..., hlm. 93-94

${ }^{43}$ Yohanes Indrakusuma, Kasih, Kepercayaan ..., hlm. 161.

${ }^{44}$ Yohanes Indrakusuma, Ketujuh Karunia ..., hlm. 97.

45 Koen de Meester, Tangan Kosong ..., hlm. 63.

${ }^{46}$ K. Prent - J. Adisubrata - W.J.S. Poerwadarminta, Kamus Latin-Indonesia (Yogyakarta: Kanisius, 1969), hlm. 757.
} 
maka disimpulkan bahwa kata "kudus" sinonim dengan suci. ${ }^{47}$ Dalam bahasa Yunani, ada dua kata yang dipergunakan untuk menerjemahkan kata kudus yaitu heiros (ilahi) dan hagios (mendahsyatkan). Dalam Septuaginta, kata hagios digunakan untuk menerjemakan kata Ibrani, kados. Kados merupakan bentukan dari kata kerja: qadash (menyucikan), kata sifat: qados dan kata benda: qodes. ${ }^{48}$

Dalam lingkup Ibrani, kata qadash (menyucikan) dihubungkan secara rekat dengan kata khadash (bersinar). Qadash diturunkan dari akar kata qad yang berarti memotong. Bentukan kata kerja qadash (menyucikan), kata sifat qados dan kata benda qodes menjadi kata kados mengungkapkan arti yang sangat mendalam, yaitu "sesuatu yang disisihkan, dipisahkan dari dunia untuk Allah". ${ }^{49}$

Dengan demikian, kados serentak mengungkapkan keterpisahan antara Allah dalam kedudukan-Nya yang istimewa dengan manusia dan kesatuan-Nya (persekutuan) dengan manusia cipataan-Nya. Apabila kata kados diterjemahkan dengan kata "kudus", maka maksud yang terkandung di dalamnya adalah "pemisahan antara kedudukan Allah yang kudus dengan hidup duniawi yang harus dikuduskan melalui kualitas rohani, etika serta moral yang berlandaskan pada hubungan dengan Allah sendiri. ${ }^{50}$

Pandangan Theresia mengenai kekudusan ini merupakan suatu ajaran yang membebaskan banyak orang. Dengan ini, ia menyadarkan banyak orang bahwa kekudusan itu terbuka bagi semua orang. Bagi Theresia, kekudusan tidak terdapat pada mati raga yang luar biasa hebatnya, tidak dalam penyiksaan diri yang besar, dan tidak dalam mukjizat yang dilakukan. Tetapi bagi Theresia cinta yang besar kepada Allah itu harus diwujudkan dalam kesetiaan yang terus-menerus dengan melakukan tugas-tugas harian yang kecil dan sederhana. Melalui kesetiaan dalam melakukan tugas-tugas kecil itu dan didorong oleh cinta

\footnotetext{
47 Departemen Pendidikan Nasional, Kamus Besar ..., hlm. 608 dan 1096; bdk. Adolf Heuken, "Kudus" dalam Ensiklopedi Gereja, Jilid V, Ko-M Jakarta: Yayasan Cipta Loka Caraka,2005), hlm. 93-94.

${ }^{48}$ T. Jacobs, Dinamika Gereja (Yogyakarta: Kanisius, 1979), hlm. 99-100.

49 Adolf Heuken, Ensiklopedi Gereja, Jilid V ..., hlm.93-94; bdk. T. Jacobs, Dinamika ..., hlm. 100

${ }^{50}$ Adolf Heuken, Ensiklopedi Gereja, Jilid V ..., hlm.95-96.
} 
yang besar kepada Allah, Theresia menyenangkan hati Allah serta menyelamatkan jiwa-jiwa kepada Allah. ${ }^{51}$

\section{Meneladani Jalan Kekudusan Santa Theresia Lesieux}

Kekudusan dalam diri Theresia tidak terletak pada perbuatanperbuatannya yang besar dan mencolok. Tetapi ia menampakkan cahaya kekudusan itu dalam kesetiaan terhadap tugas-tugas yang sederhana dalam hidup setiap hari. Ia sungguh menghayati segala tugas-tugas yang diberikan kepadanya dengan cinta yang mendalam. ${ }^{52}$ Dengan setia terhadap segala tugas yang diberikan kepadanya, Theresia telah mewujudkan sikap heroik dalam perkara-perkara kecil. Melalui teladan Theresia, Allah menunjukkan kebesaran-Nya dalam hal-hal biasa yang sering dipandang remeh oleh banyak orang. ${ }^{53}$

\section{Menekankan Sikap Kepercayaan akan Allah}

Kepercayaan kepada Allah adalah sikap hidup yang sangat penting berhadapan dengan situasi dunia saat ini dimana banyak orang mengalami keputusasaan. Dengan caranya sendiri, Theresia menunjukkan suatu arti pengharapan Kristiani kepada sesamanya. Ia mewartakan secara baru bagaimana manusia harus hidup sesuai dengan rencana Allah. Ia berjuang untuk membawa manusia kembali kepada Allah dengan memberikan teladan sikap pengharapan dan kepercayaan kepada Allah. ${ }^{54}$

Kepercayaan menurut Theresia berakar pada iman akan Allah sebagai Bapa yang Maharahim yang memelihara dan mengatur segala sesuatu dengan cinta-Nya demi kebaikan anak-anak-Nya. ${ }^{55}$ Kepercayaan akan Allah mampu menyelamatkan manusia melalui penjelmaan-Nya dalam diri Yesus Kristus. Melalui sengsara, wafat, dan kebangkitan, Yesus Kristus menganugerahkan rahmat kepada setiap orang yang

\footnotetext{
51 Yohanes Indrakusuma, Kasih, Kepercayaan ..., hlm. 113-114.

52 A. Sudiarja, Lima Kuntum ..., hlm. 34.

53 Yohanes Indrakusuma, Kasih, Kepercayaan ..., hlm. 168.

${ }^{54}$ Yohanes Indrakusuma, Kasih, Kepercayaan ..., hlm. 122.

55 Yohanes Indrakusuma, Kasih, Kepercayaan ..., hlm. 120.
} 
percaya kepada-Nya. Ia menganugerahkan rahmat pengampunan, ketabahan, cinta, kesempurnaan dan bahkan kehidupan kekal. ${ }^{56}$

Dengan sentuhan-sentuhan rahmat Allah ini, manusia diubah untuk menyerupai Yesus Kristus agar hidup bagi kemuliaan Allah Bapa dan bersatu dengan Tritunggal Mahakudus. Oleh karena itu, manusia harus berani menyerahkan diri kepada kuasa ilahi dan berpasrah diri kepada-Nya agar Allah mengubah hati setiap orang dan menjadikan manusia serupa dengan diri-Nya. ${ }^{57}$ Di dalam sikap percaya dan pasrah kepada Allah ini Theresia mengungkapkan kerinduannya untuk menjadi kudus dan harapan ini hanya ia sandarkan pada Kristus. Ia tidak pernah ragu sedikit pun untuk sampai pada cita-cita kekudusan ini. ${ }^{58}$

Cita-cita kekudusan itu pula yang menumbuhkan kerinduan Theresia yang terbesar untuk bersatu dengan Allah sehingga pandangannya hanya selalu terarah kepada surga. Karena kerinduannya yang besar untuk bersatu dengan Allah ini, ia juga selalu terdorong untuk menemukan kebaikan tertinggi dalam hidupnya. Dapat dimengerti bahwa seluruh hidup Theresia hanya dikuasai oleh perkara-perkara surgawi semata sehingga ia tidak membiarkan apapun menghalanginya untuk memperoleh kekudusan itu. Dengan sikap percaya dan pasrah kepada Allah ini, Theresia tidak pernah mundur dalam segala kesulitan dan hambatan yang terjadi padanya. Ia bahkan menerima kesulitan yang terbesar dalam hidup panggilannya yaitu cobaan batin pada akhir hidupnya demi memurnikan iman dan harapannya. Inilah yang membuat Theresia tidak pernah putus asa karena kepercayaannya yang teguh kepada Allah. Ia yakin bahwa dirinya sedang terarah kepada Bapa yang Mahabaik dan Mahakuasa. ${ }^{59}$

\section{Hidup pada Saat Ini}

Theresia mengatakan bahwa hidup pada saat ini berarti hidup berdamai dengan Allah dalam kepercayaan total kepada-Nya. Jika seseorang menyerahkan hidupnya dalam kepercayaan total kepada Allah maka ia tidak akan memikirkan diri sendiri dengan terjebak pada masa

\footnotetext{
${ }^{56}$ Ida Friederike Gorres, Wajah Tersembunyi ..., hlm. 131.

${ }^{57}$ Yohanes Indrakusuma, Ketujuh Karunia ..., hlm. 9.

${ }^{58}$ Yohanes Indrakusuma, Kasih, Kepercayaan ..., hlm. 123.

${ }^{59}$ Yohanes Indrakusuma, Kasih, Kepercayaan ..., hlm. 122-123.
} 
lampau dan tidak kuatir akan masa depan. Dalam hal ini Theresia berpegang pada sabda Yesus, "Sebab itu janganlah kamu kuatir akan hari esok karena hari esok mempunyai kesusahannya sendiri. Kesusahan sehari cukuplah untuk sehari" (Mat 6:34). Oleh karena itu dalam hidupnya, Theresia sungguh-sungguh hidup untuk saat ini. Ia menuliskan demikian:

"Kita yang menempuh jalan cinta kasih tidak boleh kuatir akan apapun juga. Seandainya saya tidak menderita dari saat ke saat, maka saya tidak mampu tetap bersabar. Saya hanya melihat masa sekarang ini. Saya melupakan masa lampau dan saya juga tidak mau melihat masa depan dengan segala kekuatiran." 60

Theresia hidup semata-mata hanya pada saat ini (pada waktu ia masih hidup) dan tidak mau mundur ke masa lalu atau melihat masa depan. Sikap yang dilakukan oleh Theresia ini merupakan buah terindah dari penyerahan dirinya kepada Allah. Melalui penyerahan diri kepada Allah, Theresia selalu mengandalkan Allah dalam hidupnya. Ia terbuka terhadap bimbingan Roh Kudus sehingga ia tidak pernah menyimpang dari rencana Allah.

\section{Bersabar dalam Penderitaan}

Dalam hidupnya, Theresia tidak dapat menghindari penderitaan. Penderitaan merupakan ujian yang harus dihadapinya. Ia mengatakan bahwa orang yang berani menghadapi penderitaan adalah orang yang rendah hati dan melaksanakan kehendak Allah. Sementara mereka yang tidak siap untuk menderita adalah orang yang tidak sabar dan mengingkari Allah. Theresia sungguh meneladani Yesus Kristus yang telah mengalami penderitaan karena taat pada kehendak Allah. ${ }^{61}$ Penderitaan yang dialami oleh Yesus itu, ia renungkan ketika banyak terjadi penderitaan dalam hidupnya. Misalnya, ketika sedang berhadapan dengan tingkah laku yang buruk dari saudari-saudarinya di biara, ketika ia dituduh memecahkan pot bunga, ketika pimpinan biara tidak menyukainya. ${ }^{62}$

\footnotetext{
${ }^{60}$ Yohanes Indrakusuma, Kasih, Kepercayaan ..., hlm. 136-137

${ }^{61}$ A. Sudiarja, Lima Kuntum ..., hlm. 36.

${ }^{62}$ Theresia dari Lisieux, Aku Percaya ..., hlm. 151.
} 
Menjelang tahun terakhir hidupnya yaitu ketika Paskah tahun 1896 ia mengalami pencobaan iman yang besar. Ia menghadapi godaan untuk menyangkal iman dan pengharapan. Pencobaan yang dialaminya ini berlangsung sampai ia menghembuskan nafasnya yang terakhir. Pencobaan yang dialaminya merupakan suatu penderitaan yang hampir tidak dapat dipahami. Selain mengalami godaan untuk menyangkal iman dan pengharapan, ia juga mengalami penderitaan fisik yang hebat. Theresia menderita penyakit radang paru-paru dan beberapa kali muntah darah. Sakit yang dialaminya itu semakin lama semakin bertambah parah sampai menjelang kematiannya tanggal 30 September 1897. Namun ia tidak merasa gentar, cemas seperti yang dialami orang pada umumnya. Meskipun ia tahu bahwa sebenarnya hidupnya terancam, Theresia menanggung semua penderitaannya itu dengan gembira karena menyerahkan hidupnya secara total kepada Allah yang Maharahim. ${ }^{63}$

Theresia mengutip kembali apa yang dikatakan oleh rasul Paulus, "saya memenuhkan pada badanku, apa yang belum dipenuhkan pada penderitaan Kristus." (bdk. 2Kor 4:10, 11). Dari sini ia merenungkan bahwa rasa sakit pada badan yang ia alami merupakan penderitaan manusia yang paling penuh. Dari penderitaan Yesus Kristus, ia belajar bagaimana menjadi taat dan tetap setia terhadap Allah. Di samping belajar menjadi taat dan setia kepada Allah, Theresia juga ingin menampakkan betapa besarnya cinta Allah kepada manusia. Ia mengatakan bahwa cinta Allah itu tampak dalam kebebasan manusia untuk mencintai-Nya. Oleh karena itu, Allah akan membalas dengan cinta-Nya setiap jiwa yang mencintai-Nya dengan tulus dan bebas. ${ }^{64}$

\section{Refleksi}

Paus Fransiskus dalam seruan apostoliknya Gaudete et Exsultate no. 14 dan 96, menuliskan bahwa Allah adalah Bapa yang Mahakudus. Semua manusia diciptakan oleh Allah yang Mahakudus sehingga dari kodratnya, manusia adalah ciptaan yang kudus. Semua manusia ambil bagian dalam kekudusan Allah dan dipanggil kepada kekudusan, yaitu bersatu dengan Allah yang Mahakudus. Allah juga memberdayakan

63 Ida Friederike Gorres, Wajah Tersembunyi.., hlm. 506-511; bdk. A. Sudiarja, Lima Kuntum..., hlm. 33-34.

${ }^{64}$ Ida Friederike Gorres, Wajab Tersembunyi ..., hlm. 509. 
manusia dengan Roh-Nya untuk menyatakan dan memancarkan kekudusan-Nya kepada dunia melalui cara beradanya dan melalui pekerjaan-pekerjaan harian yang dipercayakan Allah kepadanya. Melalui seruan apostoliknya, tersebut Paus Fransiskus menjelaskan bahwa kekudusan itu nyata dapat dilakukan oleh setiap orang dengan cara melakukan hal-hal kecil dan sederhana dengan kasih dalam kehidupan sehari-hari. Baginya tindakan apapun yang dilakukan karena kasih, bukan karena dorongan keinginan manusiawi semata, hal itu diberdayakan dan digerakkan oleh Allah sendiri.

Kristus menyerahkan diri-Nya bagi Gereja-Nya, menguduskan dan memberdayakan Gereja-Nya untuk menghayati dan meneruskan misi kekudusan-Nya kepada dunia agar semua bangsa menjadi bangsa yang kudus. Dalam meneruskan misi kekudusan Kristus ini, Umat Beriman harus sadar bahwa jantung dan nadi perutusan-Nya adalah belas kasih. Kristus menghendaki agar Umat Beriman menyatakan tindakan belas kasih dalam pekerjaan harian yang sederhana, terutama dalam perjumpaan dan interaksi dengan sesama. Misi belas kasih Gereja ini harus diwujudkan dalam tindakan yang jujur dan adil; bertanggung jawab dan dipercaya; tidak membenci walaupun dibenci, tidak terpengaruh oleh pengaruh negatif yang menghancurkan, tidak mudah tersinggung, iri dan lain-lainnya. ${ }^{65}$

Sebagai biarawati Karmel, Theresia sudah menunjukkan keutamaan dari kepribadiannya. Keutamaan Theresia ini adalah kerendahan hati yang menyadarkan dia akan kekecilan dan kelemahan dirinya. Selain kerendahan hati yang dimilikinya, Theresia juga memiliki keutamaan lainnya yaitu kerinduannya yang amat mendalam terhadap Ekaristi, hubungan cintanya terhadap Bunda Maria yang dilukiskan seperti seorang kanak-kanak, kepercayaan dan kepasrahan total dirinya dalam relasi dengan Allah, kerelaan dirinya untuk selalu berkurban dan yang terutama dari semuanya ialah cinta yang tanpa pamrih dari dirinya hanya untuk menyenangkan Yesus dan kerinduan untuk menyelamatkan jiwa-jiwa kepada Yesus.

\footnotetext{
${ }^{65}$ Franz Magnis Suseno, Beriman dalam Masyarakat: Butir-butir Teologi Kontekstual (Yogyakarta: Kanisius, 1993), hlm.153-155.
} 
Dalam melakukan semua keutamaan yang ada padanya, Theresia selalu mengandalkan Roh Kudus sebagai pembimbing utamanya. Sebagaimana terdapat dalam keutamaan hidupnya yaitu penyerahan dirnya hanya kepada Allah, Theresia ingin bertumbuh dalam persatuan dengan Allah. Namun, apa yang dialami olehnya, tentu saja dipengaruhi oleh spiritualitas dan kehidupan dalam biara Karmel. Theresia menamakan pengalaman-pengalaman hidupnya ini sebagai jalan kecil dengan mau dan setia mengerjakan perkara-perkara kecil dengan cinta dan sukacita yang besar untuk menjadi kudus dan mencapai kesempurnaan hidup bersama Allah.

\section{Penutup}

Pengalaman hidup Theresia memberikan suatu pengertian yang mendalam mengenai hidup rohani. Hidup rohani itu tampak dalam jalan kekudusan dan kesempurnaan Dalam seluruh hidupnya, Theresia menghayati sabda yang dikatakan Yesus di dalam Injil, "Barangsiapa setia dalam perkara kecil, dia juga akan setia dalam perkara besar. Dan barangsiapa yang tidak setia dalam perkara kecil, juga tidak akan setia dalam perkara-perkara besar". Dengan ini, Theresia mau menunjukkan nilai-nilai penting yang terkandung dalam perkara-perkara kecil yang sering dipandang sepele oleh banyak orang, bila dilakukan dengan cinta dan sukacita yang besar akan menghantar setiap orang kepada kekudusan.

Menurut Theresia, dengan setia melakukan tugas yang paling kecil dalam cinta yang besar dan penuh sukacita, setiap orang akan mencapai kekudusan dalam hidup setiap hari. Pandangan Theresia mengenai kekudusan ini meluruskan kembali suatu pandangan yang sering keliru mengenai jalan menuju kekudusan. Kebanyakan orang berpikir bahwa kekudusan itu hanya dapat dicapai dalam perkara-perkara besar seperti, bermati raga, puasa, penyiksaan diri dan melakukan mukzijat. ${ }^{66}$ Pengalaman dan pengahayatan Theresia akan kesetiaan dalam perkara kecil membuka pandangan dunia dan kita semua bahwa semua orang dapat menjadi kudus dan mencapai kesempurnaan.

${ }^{66}$ Yohanes Indrakusuma, Kasih, Kepercayaan ..., hlm. 145. 
Semoga tulisan yang bertemakan "Kesetiaan dalam perkara kecil sebagai jalan kekudusan" menurut teladan Santa Theresia Lesieux ini berguna dan menjadi sangat relevan untuk semua orang beriman dalam menapaki jalan kekudusannya. Melalui teladan hidup Theresia yang setia terhadap tugas-tugas kecil dan sederhana, semua orang beriman, yang sudah dibaptis semakin menyadari dan menghidupi martabat luhur dari semua bentuk pekerjaan dan tanggungjawabnya sesuai dengan pilihan hidup dan panggilannya masing-masing dengan menghargai, mencintai, dan mengerjakan perkara-perkara kecil, pekerjaan kecil dan sederhana, dengan cinta dan sukacita yang besar. Bila orang melakukan dengan setia akan tugas dan tanggungjawabnya, terutama setia dalam perkara kecil dan mengerjakannya dengan cinta dan sukacita yang besar, ia sudah berada dalam jalan kekudusan.

$===0000===$ 
Lagos, Jurnal Filsafat-7ealogi, Val 13. No. 1. Damuari 2016

\section{DAFTAR PUSTAKA}

Heuken, Adolf. Kudus dalam Ensiklopedi Gereja, Jilid V, Ko-M. Jakarta: Yayasan Cipta Loka Caraka. 2005.

Darmawijaya, St. Kesetiaan Suatu Tantangan. Yogyakarta: Kanisius. 1989.

Departemen Pendidikan Nasional. Kamus Besar Bahasa Indonesia. Jakarta: Balai Pustaka. 2002.

Gorres, Ida Friederike. Wajah Tersembunyi: Kehidupan Theresia Lisieux, (Judul asli: Het Verborgen Gelaat) diterjemahkan oleh biarawati Karmel Bajawa.Yogyakarta: Kanisius. 1985.

Hurter, Maria. Santa Theresia dari Anak-Anak Yesus. Ende: Arnoldus. 1963.

Indrakusuma, Yohanes. Ketujuh Karunia Roh Kudus Dalam Hidup St. Theresia Lisieux. Jawa Barat: Pertapaan Shanti Buana. 2004.

Penyelenggaraan Ilahi Jilid 2. Jawa Barat: Pertapaan Shanti Buana. 2009.

Kasih, Kepercayaan dan Pasrah: Jalan Kanak-kanak Rohani Theresia Lisieux. Jawa Barat: Pertapaan Shanti Buana. 2003.

Jacobs, T. Dinamika Gereja. Yogyakarta: Kanisius, 1979.

Jestice, Phyllis G., Ed. Holy People of The World: A Cross-Cultural Encyclopedia. Santa Barbara, California: ABC-CLIO. 2004.

Prent, K. -J. Adisubrata-W.J.S. Poerwadarminta, Kamus Latin-Indonesia. Yogyakarta: Kanisius. 1969. 
Konsili Vatikan II, "Konstitusi Dogmatis tentang Gereja" (Lumen Gentium), dalam Dokumen Konsili Vatikan II, diterjemahkan oleh R. Hardawiryana. Jakarta: Dokumentasi dan Penerangan KWI-Obor. 1993.

"Konstitusi Pastoral Tentang Gereja di Dunia Dewasa ini" (Gaudium et Spes), dalam Konsili Vatikan II, diterjemahkan oleh R. Hardawiryana. Jakarta: Dokumentasi dan Penerangan KWI-OBOR. 1993.

Laforest, Ann. Theresia of Lisieux: The Way to Love. Wisconsin: Sheed and Ward. 2000.

Leon, Xavier-Dufuor. Ensiklopedi Perjanjian Baru (judul asli: Dictionnaire du Nouveau Testament), disadur oleh Stefan Leks dan A. S. Hadiwiyata. Yogyakarta: Kanisius. 1990.

Leteng, Hubertus. Spiritualitas Imamat Motor Kehidupan Imam. Maumere: Ledalero. 2003.

Liseux, Theresia. Pesan Terakhir Theresia Lisieux Menuju Hidup Baru (Judul Asli Ik Ga Het Leven Binnen).Yogyakarta-Ende: Kanisius-Nusa Indah. 1985.

Aku Percaya akan Cinta Kasih Allah, diterjemahkan oleh biarawati Karmel Bajawa. Yogyakarta: Kanisius. 1985.

- The Autobiography of Therese of Lisieux: The Story of a Soul, diterjemahkan oleh John Beevers. New York: Doubleday and Company Inc. 1957.

Meester, Koen de. Tangan Kosong Theresia dari Lisieux, diterjemahkan oleh M. Stignter dan C. Verbeek. Yogyakarta, Ende: Kanisius, Nusa Indah. 1985.

Obar, Elizabeth Ruth. Theresia dari Lisieux: Jalan Kecil Menuju Kesucian. Yogyakarta: Kanisius. 2007. 
Olla, Paulinus Yan. Dipanggil Menjadi Saksi Kasih. Yogyakarta: Kanisius. 2008.

Paus Fransiskus, Seruan Apostolik Paus Fransiskus 19 Maret 2018: Gaudete et Exsultate (Bersukacita dan Bergembiralah) (Seri Dokumen Gerejawi No. 106), diterjemahkan oleh R.P.T. Krispurwana Cahadi SJ. Jakarta: Departemen Dokumentasi dan Penerangan KWI. 2019.

Sudiarja, A. Lima Kuntum Bunga Gereja. Yogyakarta: Kanisius. 2015.

Sunarka, J. "Kaul Kemurnian di Zaman Maya”, dalam A. Sudiarja dan Bagus Laksana (ed.), Berenang Di Arus Zaman: Tantangan Hidup Religius di Indonesia Kini. Yogyakarta: Kanisius. 2003. 